\title{
Chamorro Language
}

National Cancer Institute

\section{Source}

National Cancer Institute. Chamorro Language. NCI Thesaurus. Code C153876.

An Austronesian language spoken by the Chamorro people of Guam and the Nothern Mariana Islands. 